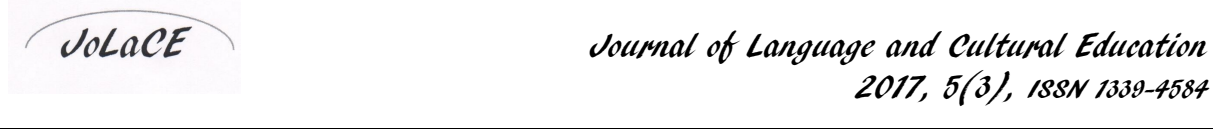

园

DOI: $10.1515 /$ jolace-2017-0028

\title{
Expression evaluation of a quoted author in academic discourse: Inter-language (Lithuanian and English) case study
}

\author{
Vilija Celiešienė, Virginija Stankevičienẻ \& Daiva Zavistanavičienė \\ Kaunas University of Technology, Lithuania \\ virginija.stankeviciene@ktu.lt
}

\begin{abstract}
The aim of this article is to analyse subject expression evaluation of the non-author language, i.e. the author whose thoughts, discoveries, research results or assumptions are relied on in scientific texts in Lithuanian and English languages, elucidate both universal properties of expression evaluation and the specific ones determined by a particular language and culture. Publication texts of education science field of social science area were selected for the research. Expression evaluation of a quoted author was analysed identifying neutral (surname / name and surname, nationality and residence, scientific and professional activity, time, scientific discoveries, activity achievements, family relations) and subjective (logic and emotional evaluation) attributes. It was determined that education science texts of both languages, Lithuanian and English, do not exhibit a variety of quoted author expression. No examples purveying all possible semantic meanings of attributes were found in both languages. Prevalence of neutral attributes of science subjects and similar aspects of usage of some attributes (surname / name and surname, nationality or residence) reveal general citation traditions determined by universal scientific text regularities rather than a particular language or culture. On the other hand, some tendencies were observed characteristic only to the texts of one or another language and reflecting specific evaluation features of science subject. In the articles of native English speakers, scientific discoveries, results of scientific activity of quoted authors are emphasised whereas Lithuanian authors are more liable to highlight scientific or professional activity and time. Moreover, it is essential to mention that every text represents its author's personality to some extent. Thus, the choice of the particular means of expression can be determined by personal qualities of an author.

Keywords: academic discourse, intertextuality, subject of non-author language, attributes of science subjects, evaluation expression.
\end{abstract}

\section{Introduction}

During a long-term analysis of academic discourse, particular features of scientific language were provided: objectivity, accuracy, conservatism and 
neutrality, the peripheral role of a scientific text author is underlined. However, recent research (Myers, 1989; Latour, 2002; Hyland, 2005, etc.) encompassing multifaceted analysis of academic discourse developed perception of the latter. Peculiarities of scientific text structure, nature of argumentation, rhetorics, intercultural and interdisciplinary features, etc. are widely analysed. According to Šinkūnienè (2014, p. 7), the result of such research makes it usual to speak not only about one universal academic discourse but different academic discourses, the variety of which is obvious from the standpoint of genre, discipline and culture. Recently, a written academic discourse is noted to be developed as a dialogue where not only are facts and information considered important but also how an author evaluates their reliability, significance, how he tries to persuade a reader in fairness of his viewpoint (Smetona \& Usonienè, 2012, p. 125).

Linguistic evaluation has been explored by many foreign scientists for many decades (Bell, 1991; Thompson \& Hunston, 2000; Martin \& White, 2006; Bednarek, 2006, ect.). In compliance with Hunston and Thompson (2000, p. 5), evaluation is a wide term, which defines a speaker or writer's position or attitude, approach, feelings about reality or statements about which he or she speaks. This attitude can be related to certain beliefs, obligations, duties or any other sets of values (Thompson \& Hunston, 2000, p. 5). Šinkūnienè (2011, p. 10) has mentioned that the majority of ongoing scientific projects carried out during the last two decades, prepared sets of scientific articles related to the research of an author's position set the aim to reveal grammatical, rhetorical, stylistic features of academic discourse texts and study how inherent cultural issues and peculiarities of genre and disciplines impact the authors' expression in scientific language. Scientific works, articles intended for scientific discourse research and disclosure of intercultural differences provide the insight what determines one or another choice of expression evaluation means - traditions of a scientific area, its specificity or the language itself? The comparative researches of English, German, French, Russian and Bulgarian languages (Vassileva, 1998), English and Spanish languages (Martin, 2003; Mur Duenas, 2007), English, French and Norwegian languages (Breivega et al., 2002), Norwegian, French and English languages (Flottum et al., 2006) are to be pointed out.

Evaluation in Lithuania is considered to be a new phenomenon, thus this area still lacks research. Generally, evaluation is applied as a tool to describe various indicators, for instance in economics, management sciences. However, it is not considered to be an object of the research itself. From the linguistic approach, this phenomenon has been only analysed in individual works. Researches of Damošius (2007), Ryvitytė (2005), Čičirkaitė (2008), Šinkūnienė (2010), Šlepikienè and Linkevičienè (2013) are to be referred to. Peculiarities of author position expression in multilingual academic texts have not been studied widely in 
Lithuanian linguistics. Several works were published (Ryvitytė, 2005, 2008; Šinkūnienè, 2011, 2012; Ruskan, 2012) where evaluation and author position expression in the Lithuanian scientific language and its specificity comparing it to the English language were researched.

Intertextuality in the context of evaluation of a non-author language subject in the academic discourse of the English language is more extensively explored in the works of discourse researchers where disciplinary tendencies are discussed, various classifications of citation and types of other thought proclamation are suggested (White, 2004; Hood, 2010; Hunston \& Thompson, 2000). Such researches are not abundant in Lithuania. The following researches must be named, i.e. evaluation clarity and author position expression in Lithuanian scientific language by Damošius (2007) and the research of expression of attributes of science subjects in popular science texts by Petrènienè (2005). Thus, the need for a deeper research of intertextuality of Lithuanian scientific text is obvious, especially inter-language, intercultural focusing on other author text integration into a new text, relation of an author with the subject of a non-author language and its evaluation expression.

The aim of this research is to analyse the subject of a non-author language, i.e. expression evaluation of an author whose thoughts, discoveries, research results or assumptions are relied on in scientific articles in English and Lithuanian, to reveal universal features of expression evaluation and specific ones determined by a particular language and culture. Hence, the executed inter-language research will assist in determining different and universal societal attitudes of academic discourse from the point of view of non-author language subject evaluation, determine characterisation tendencies of non-author language subject, also it will allow to purvey useful insights about peculiarities of academic discourse determined by different academic cultures.

The following methods are employed in the study: the analysis of scientific literature; descriptive method; comparative method.

Recently, a scientific article has become one of the most popular genres in academic discourse research. The scientific article in many disciplines remains the essential tool of the obtained scientific result dispersion with the help of which scientists communicate their insights and consolidate in the academic world (Hyland, 2005, p. 89-90). Texts of education science publications of social science area were chosen for this research. As Duszak (1997, p. 292) comments, discourse specificity determined by the language and culture is better revealed in texts of humanitarian and social sciences in comparison with exact sciences. Discourse specificity is better depicted in inter-language (Lithuanian and English) analysis. Examples of Lithuanian discourse are selected from publications of „Pedagogika“, Vol. 122 and 124 (2017), an international periodical peer-reviewed journal of 
research papers of Lithuanian University of Educational Sciences. The English examples were taken from Journal of Pedagogic Development, Vol. 6 and 7 (2016). It is relevant to mention that in pursue of research data accuracy native authors of both Lithuanian and English texts were selected.

\section{Theoretical background}

Academic discourse is essentially intertextual as it is relied on previous investigations. Melnikova (2003, p. 6 p.) claims intertextuality to be the interaction between the text of an author and a foreign one, which allows a text reader to interpret the author's thoughts in his own way. Intertextuality of scientific style texts is systematically emphasized. In accordance with Bitinienè $(2005$, p. 68), every text is a component of two-direction communication process, which implicates subject interaction of scientific activity, their dialogue and also displays development of certain scientific knowledge. As stated by the author, text intertextuality is determined by relation of scientific activity subjects and direction of information creation rather than linguistic factors (Bitinienè, 2005, p. 68). This is one of the most substantial features of scientific text as a newly created text will someday become information source for created texts after it. In a scientific text, where it is obligatory to refer to works of other scientists in the background of which new text originality revealed as a certain phenomenon of academic culture, intertextuality is most frequently expressed by quoting, paraphrasing or referring.

Any citation (direct or indirect) is related to the text of other author, i.e. with the subject of a non-author language, the author whose thoughts, discoveries, research results or assumptions are referred to. Thus, the text author has an essential role. In conformity with Latour (2002, p. 53-54), it is compared to the role of a conductor: the text author as a conductor, finds suitable places for scientific discourse participants: some are quoted, the works of others are just referred to, critical readers and their contradictions are visualised. After thorough consideration, an author selects a quoted text and transfers it to the author's text, as Damošius (2007, p. 52) claims, ,a peculiar selection of language and expression is carried out, when a quotation from non-author text is taken as the most important element of the entire text and it is transferred to the new environment, to the author's text as an „alien“". Therefore, an indirect interaction occurs between the quoting and the quoted authors: „the former acknowledges the input of the latter to the bulk of scientific knowledge mentioning it in his text as if he returns the honorary debt" (Voverienè, 2013, p. 135). Non-author language is one of the ways to emphasize personal arguments. Frequently quoted statement, as Hyland (1998, p. 85) argues, eventually becomes a fundamental scientific truth. On the other hand, a traditional citation will always be intertextual, i.e. „when a distinguished foreign word of an author occurs in a text it is a sign of the other 
system (even if it is used to continue linguistic activity successfully, i.e. to maintain story linearity), and it still disrupts a story linear dispersion on a minor scale" (Melnikova, 2003, p. 42). In order to maintain text integrity and create a common textual space, citations are customised to the text author, thus, they are modified in one way or another. Hereby, it can explain a recent tendency to paraphrase a non-author text and eliminate boundaries between the author and non-author text as much as possible.

As Compagnon (2000) posits, quoting as one of the ways of non-author language expression is never impersonal, i.e. there is always a quoting person behind it, who is related to the chosen citation by one way or another. An appropriate citation (or other non-author language rendering way) introduction language is selected to render this meaningful relation. The relationship between an author and the information provided, i.e. non-author language, is communicated by certain means of evaluative expression embodying his/her attitude to both non-author language and its author. However, evaluation, in accordance with Ryvityte (2005, p. 97), is a complicated phenomenon as not always evaluation in the text is clearly expressed. Most frequently, it is only implied where the boundary between praise and criticism can be obscure as „people do not always use the words good and bad to express their opinion. Furthermore, praise and criticism can be situation-dependent: in one situation detailed means a positive evaluation, in the other - negative“. Thus, the citation environment was started to be researched in order to determine if it was quoted evaluating positively, agreeing and referring to the quoted source or vice versa, the source is criticised and rejected (Petrauskaitè \& Šinkūnienè, 2015, p. 67). Having analysed the ratio between the author and non-author language, researchers highlight the diversity of a non-author language and its subject expression in scientific texts. Duchovski (2003, p. 5), speaking about non-author language evaluation uses the terms deep and wide citation. As the referred author states, if a few thoroughly selected sources are quoted, which are examined by various attitudes, consequently, the quoted work is accurately studied and not only are the conclusions provided but also their substantiation and evaluative attitude. It is called deep quoting. However, if numerous references without argumentation of quoted works are provided, a reader must trust the author and his conclusions. Such citation method is called wide quoting by Duchovski (2003).

Thus, researchers of academic discourse are not limited to regularity analysis of scientific activity result rendering of the author during recent decades. However, they thoroughly analyse how the author values credibility and significance of quoted facts and information in order to determine the author's relation to the provided information, i.e. evaluative attitude. Moreover, it was noted that authors of scientific texts seeking for in-depth presentation of 
information start to express their attitude from the point of view of the quoted author, i.e. cognitive information about non-author language subject (author) is provided. Studies of this nature are not abundant, however more attention of the researchers of academic discourse is devoted to them.

Damošius (2007, p. 52) analysed evaluation and author position expression in Lithuanian scientific language and he determined that non-author language subject is introduced in many ways: only surname of the quoted author can be indicated (sometimes with his name), subject of scientific research is defined according to profession, name mentioned by a personal pronoun he, collective „author" can be identified, evaluative information in respect of the quoted author and his text can be provided. Speaking of science subject expression in popular science texts, Petrènienè $(2005$, p. 92) identifies extra information about nonauthor language as attributes and emphasises the fact that frequency of attribute usage is not similar in texts of scientific style, and their expression depends on nature and thematics of the provided information. Hence, science subjects can be identified by attributes of several types: main (dominating), by which the most essential factual information is rendered (surname and name, nationality, residence, scientific and professional activity) and supplementary attributes, by which information is specified and expanded. Regarding the nature of provided information, supplementary attributes can be further subdivided into neutral (time, the most important scientific discoveries, activity achievements and family relations) and subjective attributes (Petrènienė, 2005, p. 93). The author renders his/her attitude or evaluation by subjective attributes. Scientific style texts usually contain stylistically neutral attributes which, as Župerka (2001, p. 14) claims, are selected for conveying denotative rather than emotional contents. Such logical evaluation is most commonly expressed by abstract words, for example adjectives famous, well-known, prominent. However, Petrènienè $(2005$, p. 94) argues that scientific style texts also incorporate attributes expressing emotional evaluation, expressed by metaphoric comparisons (e.g. father of cybernetics) or picturesque descriptive expressions, (e.g. hothead of quarrelsome and impossible character).

Consequently, main and supplementary attributes characterise the subject of non-author language and are to be considered as neutral introductory, whereas subjective attributes reveal the relation of the text author with both the subject of non-author language and non-author language itself, i.e. evaluative information is provided in respect to the quoted author or his text. Therefore, expression of nonauthor language subject in this study is analysed identifying neutral (main and supplementary) and subjective attributes:

1. Neutral attributes (help to determine descriptive nature of non-author language subject); 


\subsection{Main attributes (render the most essential factual information);}

1.1.1. Surname, name of non-author language subject;

1.1.2. Nationality, residence (country, city, etc.);

1.1.3. Scientific and professional activity (scientific degree, pedagogical title, profession, position, etc.);

1.2. Supplementary attributes (factual information is specified);

1.2.1. Time (age, epoch, period, exact year);

1.2.2. Scientific discoveries;

1.1.3. Activity achievements (scientific activity evaluation, awards or achievements);

1.1.4. Family relations;

2. Subjective attributes (help to determine the author's relation to the presented information, i.e. evaluative attitude);

2.1. Logic evaluation (attributes are most frequently stylistically neutral);

2.2. Emotional evaluation (it is defined by expressive descriptions)

(modified according to Petrènienė, 2005, see Figure 1)

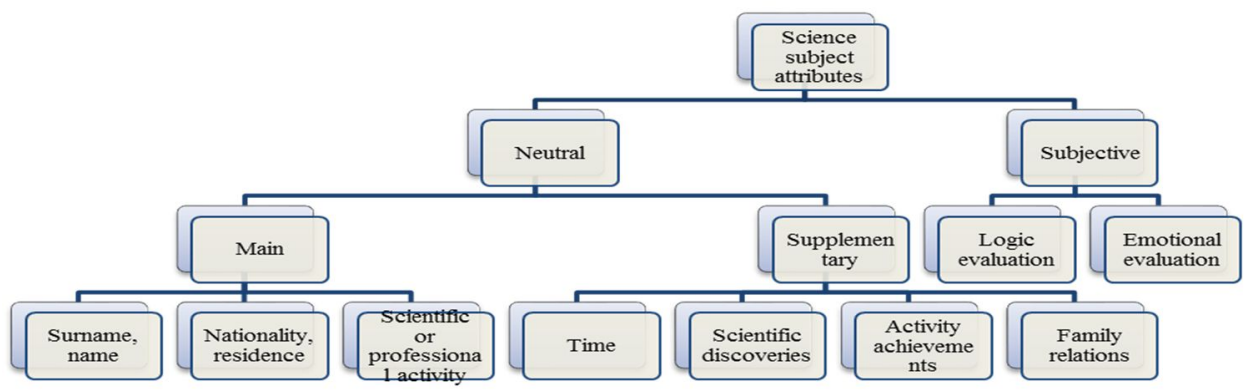

Figure 1: Attributes of science subjects (modified according to Petrénienė, 2005)

In pursuance to achieve consistency in author (subject of non-author language) description of the quoted text, the term attribute is also employed in this study. Explicit distribution of a possible semantic meaning of an attribute is theoretical guidelines of possible attribute expression. Thus, research objects found in both Lithuanian and English texts do not have to present all the examples of this distribution. Moreover, it ought to be referred that the discussed researchers Petrènienè and Damošius restricted their studies to the analysis of Lithuanian texts exclusively, which assisted in determining attribute usage tendencies in popular science and scientific texts. Our research would be the first attempt to 
disclose evaluation expression of the quoted author in academic discourse of Lithuanian and English languages.

\section{Results of the analysis}

Intertextuality in a scientific text is most frequently expressed by quoting or paraphrasing. This statement is also verified by the data of this research, which revealed that both Lithuanian and English academic discourse are intertextual, the authors base their research predominantly on the thoughts of other investigators, they quote them directly or paraphrase. Having studied articles of Lithuanian (20 articles) and English (20 articles) authors of educational area, totally 1057 citations were discovered, 467 in Lithuanian texts and 590 in English texts inclusively. Consequently, English texts of educational area are more intertextual with greater interaction of an author and foreign text. Although the difference is not highly distinct.

This research explores both direct and paraphrased citations which could be recognised in conformity with formal criteria, i.e. direct citations according to citation marks and references, paraphrased - according to absence of citation marks and references. This study indicated that paraphrased citations were more frequent in Lithuanian (78\%) and English (92\%) articles: Anot B. Bitino (2000, 62), ugdymo koncepcija vis stiprejjo, kol galutinai issitvirtino XX a. 8-ajame dešimtmetyje (11) (Vol 122, Issue 2, p. 11). Additionally, in the above scenario, the overview was the consideration of current evidence pertaining to student-centred and self-directed learning (Beckwith \& Beckwith, 2015) (Vol. 6, Issue 3, p. 28). Another review focuses on modelling harmony (Pachet \& Roy, 2001) (Vol. 6, Issue 1, p. 5). Apparently, article authors consider it more relevant not to convey other author's thoughts precisely but the information itself, which is of more general nature. Although Lithuanian authors rely on direct citations (22\%), which make the discourse more reliable and prevent misinterpretation: „Žmogus įveikia daug mentaliniu pakopu, akumuliuodamas žinias ir protu koreguodamas savo ankstesnę patirtị “ (Samalavičius, 2003, 35) (Vol 122, Issue 2, p. 78). Direct citations in English texts make only 8\% of all citations: Importantly, as Cope and Watts (2000, p. 107 and 117) recognise: 'for many entrepreneurs, the articulation of this learning process may be very difficult particularly as they may be very unused to reflecting explicitly.... [But] there is a compelling need for them to develop the attributes of the reflective practitioner' (Vol. 6, Issue 3 p. 35). Rhoads and Szelenyi (2011, p. 8-9) argue that not only do 'universities have an obligation to use their knowledge capacities to advance social life and to better the human condition', but they also have a responsibility for 'advancing global social relations' (Vol 7, Issue 2, p. 46). 
These tendencies only partially illustrate similar citation traditions of two academic societies whereas paraphrased citations are more frequent in English texts than direct ones nevertheless they prevail in the texts of both languages.

Analysing citation usage, reference integration into sentence structure must be focused on. Scientists studying peculiarities of references to sources in a scientific text rely on Swales (1990) classification model of integral and non-integral citations. Referring to Swales $(1990,148)$, integral citations are considered to be citations to the quoted source as sentence elements integrated into syntactical structure of a sentence: M. R. Warrenas, S. Hong, C. L. Rubin ir P. S. Uy (2009), aptardami i ivairias mokyklos ir šeimos bendradarbiavimo strategijas, pateiktas daugelio mokslininku, išskiria kelis bendravimo modelius (Vol. 122, Issue 2, p. 52). It is clear that Boekaerts (1999) conceptualises learning is as a dynamic state of interaction and mutual reinforcement between the student and their environment (Vol. 6, Issue 3, p. 33).

A non-integral citation is considered to be a citation when a quoted source is used only in brackets and formally is not integrated into a syntactical structure of a sentence: Pedagogas, atlikdamas esminę ugdymosi inicijavimo funkcija, suponuoja perejima nuo ugdymo technologijos prie ugdytinio kaip subjekto ir igalina jo intelektini, emocinị ir praktinị aktyvumq (Martišauskienè, 2016) (Vol. 124, Issue 4, p. 65). The apparent commonality of aims within higher education (HE) masks vast disparities in what some of these attributes actually mean, how the relevant policies are implemented, how these skills are taught and for what purposes. Indeed, scholarly production shows that these buzzwords are highly contested (Clifford \& Montgomery, 2011) (Vol. 7, Issue 2, p. 12).

In compliance with Hyland $(1999,344)$, the choice of one or another form of citation is not accidental, it indicates what the author wants to emphasize - the information itself or the quoted author. Non-integral citations prevail in both Lithuanian and English educational articles, they comprise $61 \%$ and $62 \%$ of all references respectively. Thus, the authors of both languages consider the conveyed information more significant than its author. Nevertheless, a strong relation between direct citations and their reference integration into sentence structure in English texts has been observed. Native English authors having chosen a direct citation method are not prone to integrate direct references into sentence structure. There is not a single case in the articles of twenty different authors with direct citation integration into sentence structure. Whereas $27 \%$ of direct citation references are integrated into sentence structure in the texts of Lithuanian authors: Kaip teigia D. Navickaite (2015), „Lietuvoje mokytojo atlyginimas yra truputi aukštesnis nei vidutinis, o Suomijoje truputi mažesnis - bet pagarba, prestižas ir pašaukimas tam Suomijoje tai daro vienq iš geidžiamiausių profesijų" (Vol 122, Issue 2, p. 27). 
Interesting tendencies of inter-language citation are observed studying the relationship between the choice of paraphrased citations and integral and nonintegral references. Having chosen citation paraphrasation more frequently (62\%), English authors are apt to not integrate references into sentence structure whereas the difference between the choice of integral (44\%) and non-integral (56\%) references in the texts of Lithuanian authors is less notable.

In order to get a more diverse evaluation expression of research objects the analysed texts of both languages were compiled of published articles of various authors. Although there were no examples found conveying all possible semantic meanings of attributes of both languages. Distribution of ways of quoted author characterisation in Lithuanian and English texts is showed in Picture 2. The diagram comprises characterisation data of neutral science subjects exclusively as subjective evaluation of a quoted author does not make a separate percentage group from a total number of citations. Evaluative information in relation to a quoted author and his text is always provided with neutral attributes.

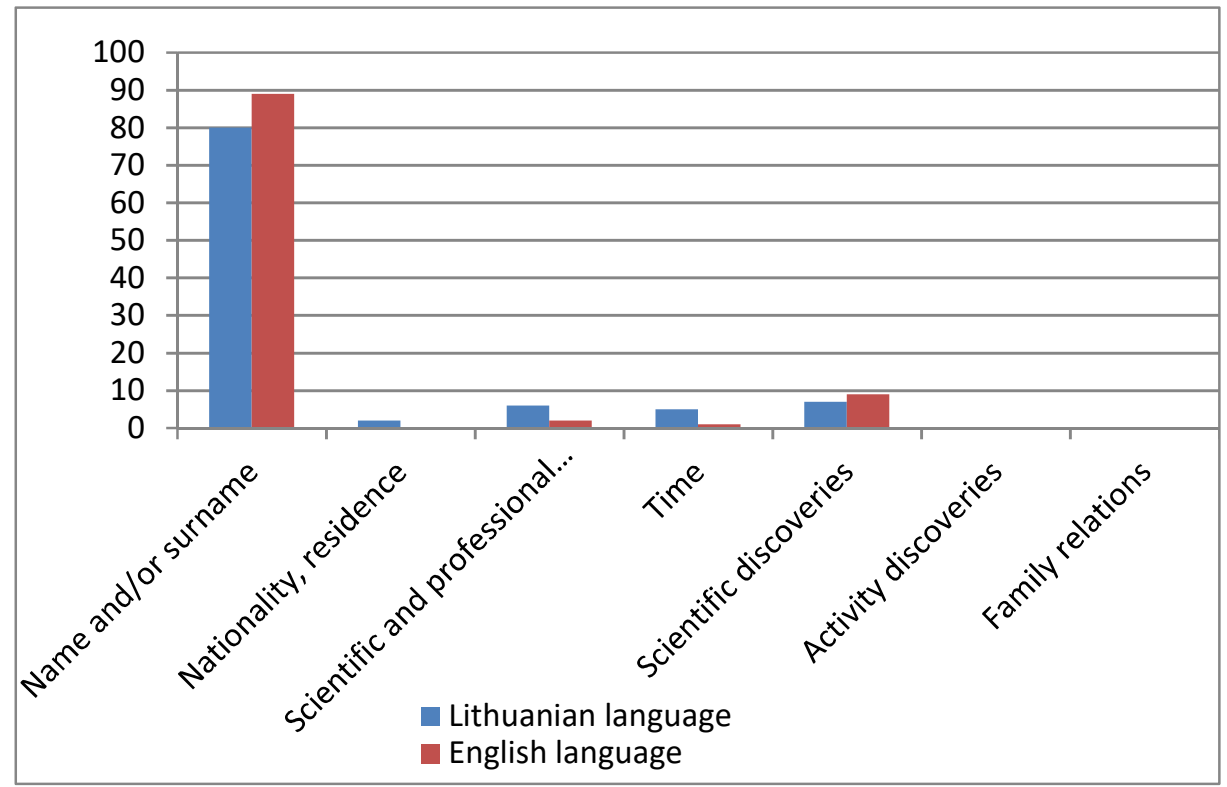

Figure 2: Frequency of ways of quoted author characterisation

In accordance with the data reflected in the diagram, five out of seven attributes are used to characterise a quoted author in Lithuanian texts, whereas in English four out of seven. Neither Lithuanian nor English authors emphasize 
achievements or family relations of the quoted author. Although authors of both languages are confined to providing the surname / name and surname of nonauthor language subject (author) in particular and choose other subject titles quite rarely but further science subject analysis allowed to provide with some insights about inter-language citation traditions in academic discourse.

Neutral attributes of science subjects characterising a subject of non-author language are dominating attributes in educational articles of Lithuanian and English authors. It shows that both Lithuanian and English authors are not apt to express subjective opinion with regard to a quoted text and they confine to the information of presentational nature. This tendency is entirely regular as it was determined by one of the most important requirements of scientific style, i.e. provide as much objective scientific information based on facts, numbers, and research data as possible.

Neutral attributes characterising a quoted author are divided into main and supplementary. Main attributes, by which factual information (surname / name and surname, nationality or residence, scientific or professional activity) is conveyed form the greatest part (89\%) of all neutral attributes found in the texts of both languages.

Defining the subject (author) of scientific research of non-author language in most cases only the author's surname / name and surname ( $91 \%$ of Lithuanian and $97 \%$ English of all main attributes) are indicated. It is relevant to note that this group consists of authors of quoted text presented by only their surname / name and surname whereas other neutral attributes are not employed: Anot B. Bitino (2000, 62), ugdymo koncepcija vis stiprejjo, kol galutinai įsitvirtino XX a. 8-ajame dešimtmetyje (Vol 122, Issue 2, p. 11). „Ugdytinio vertybiu internalizavimo ir jo squveikos su ugdytoju nuolatinis tobulinimas, padedantis ugdytiniui išskleisti savo asmenybę ir kūrybiškai veikti pasaulyje" (Aramavičiūtè, 1998, 48) (Vol 122, Issue 2, p. 22). Traxler, (2013) defines mobile learning (mLearning) as learning using mobile technologies such as mobile phones, smartphones, e-readers and tablets, and argues that these devices offer 'unparalleled access to communication and information' (Vol 6, Issue 1, p.15). The issue of ideological fit (or misfit) between the concepts of global citizenship (premised on equality, social justice, cooperation, compromise and care) and capitalism (based on dominant market forces such as competition, self-interest and materialism) has been highlighted by Cliffard and Montgomery (2014), Rhodes \& Szelenyi (2001) and Faulks (2006) (Vol 7, Issue 2, p. 48).

Prevalence of these attributes in texts of both languages can be explained by the relationship between the addressee and the addresser when the level of knowledge of both participants of communication does not differ so the text 
assigned for such a reader is not superfluous with information elements, only surname / name and surname of the quoted author are presented.

Nationality or residence of non-author language subject is rarely indicated in educational articles. This way of expression in Lithuanian texts made only $2 \%$ of all main attributes while English authors do not use these attributes at all. Apparently, authors consider the reader of their scientific articles as a specialist of the same area or the same level of knowledge. Consequently, they do not see the necessity to emphasize nationality or residence of the quoted authors as it is common knowledge for academic society of that area. Lithuanian texts most frequently specify residence as an attribute of this group: Kalifornijos psichologas L. D. Rosenas (2012) kelia klausima, kq mokytojai žino apie jaunus žmones, kurie ištisas valandas sédi prie kompiuterio, leidžia laika ịvairiuose socialiniuose tinkluose (Vol 122, Issue 2, p. 111). Lietuvoje (Juodaitytè ir Martišauskienè, 2011), kaip ir visame pasaulyje (Fenech ir Sumsion, 2007; Stamm, 2012) plačiai diskutuojama, koks turètu būti kokybiškas ikimokyklinis ugdymas(is), kokie elementai ji apibrèžia ( Vol 124, Issue 4, p. 149). Nationality is indicated very rarely: Amerikiečiu mokslininkas M. Cochranas (2011), išanalizavęs 29 valstybiu ikimokyklinio ugdymo programas, išskiria du aktualius šiandienio švietimo siekius: pirmq - $i$ ugdymo procesq integruoti visus vaikus, taip mažinant socialinę atskirtį; antrq - daugiau demesio skirti vaiku socializacijai ( Vol 124, Issue 4, p. 150).

Attributes defining scientific or professional activity are more informative than nationality or residence, thus the latter attributes are more frequent. Three times more frequent (7\%) usage of attributes indicating profession in Lithuanian texts demonstrates that Lithuanian authors are more inclined to evaluate a subject according to his duties or professional qualification than English authors. The following aspects are specified as the most frequent:

- profession: Šiam požiūriui pritaria ir ekonomistas R. Rudzkis (2012), teigdamas, kad valstybé privalo formuluoti užsakymus universitetams ir finansuoti studijas pagal tai, kokiu profesiju atstovu labiausiai reikia, o ten, kur yra studentu perteklius, skirti mažesnį finansavimą (Vol 122, Issue 2, p. 77);

- scientific and study degree: Kaip pažymi prof. B. Bitinas $(2013,458)$, siekiant veiksmingo poveikio ugdytiniui, pedagogas turi valdyti ugdymo procesa, o tam „būtina operatyvi grižtamoji informacija apie auklejamosios veiklos komponentu rezultatyvuma, todèl svarbu nustatyti, koki poveiki mokiniams padaré atskiros auklejamosios situacijos" (Vol 124, Issue 4, p. 106). But in 2000, Lorin Anderson, a former student of Bloom's, suggested a move away from the use of nouns to verbs in this taxonomy (Anderson et al, 2000) (Vol 6, Issue 3, p. 24).

- duties: Švietimo ir mokslo ministras D. Pavalkis (2013) teigia, kad aukštojo mokslo institucijos turi rengti tokius specialistus, kokiu reikia darbo rinkai (Vol 122, Issue 2, p. 77). But in 2000, Lorin Anderson, a former student of Bloom's, 
suggested a move away from the use of nouns to verbs in this taxonomy (Anderson et al, 2000) (Vol 6, Issue 3, p.24). This act was coupled with the establishment of new Teachers' Standards (2011), the cessation of 'National Strategies' (2011) and the creation of a new National Curriculum (2014), as the educational secretary at the time, Michael Gove, attempted to create a more market based provision, arguing that each school needed to be an island catering to its own needs and competing with its nearest competitors (Vol 7, Issue 2, p. 3).

Supplementary attributes, by which information is specified or expanded constitute $11 \%$ of all neutral attributes. These attributes accentuate features contributing to better perception of scientific activity of quoted authors. These attributes are classified into four groups and only examples of two groups (time, scientific discoveries, and results of scientific activity) are found in articles of both languages. Authors are not apt to specify activity achievements or family relations of the quoted author. Obviously, these attributes are insignificant for article authors or they were not inherent for subjects of non-author language.

Time attributes (publishing year of the quoted source are not considered time attribute and is regarded as inseparable reference elements) contribute to better evaluation of scientific activity in the context of history. Data of their usage displayed rather different inter-language tendencies. Although these attributes in the context of all attributes are rarely used (Table 2) but in Lithuanian articles they compose $42 \%$ of all supplementary attributes and are more frequently used than in English articles (4\% of all supplementary attributes). It indicates that in comparison with English authors, Lithuanian authors consider it more significant to define scientific achievements of non-author language subject from historical point of view. The most frequently indicated are the following:

- year: Tačiau Stasys Šalkauskis 1935 m. savo „Bendrosios pedagogikos paskaitose" pirmasis pedagogikos mokslo objektu nurodè ugdyma (Vol 122, Issue 2, p. 10); When writing across the curriculum (WAC) and writing in the disciplines (WID) pedagogies emerged in the late 1970s and early 1980s, they aimed, in part, to actualize bridging by contextualizing writing, giving students opportunities to practice the rhetorical conventions, standards of proof, and ways of knowing that characterize academic writing in various disciplines (Neff \& Whithaus, 2009; Williams,2014) (Vol. 7, Issue 1, p. 9).

- century: XX a . pedagogikos klasikai (Fullan, 1997) mokytojo veiklos pagrindu laiko moralinę branda (Vol 122, Issue 2, p. 24); Dewey (1933), a key twentieth century instigator of the concept of reflection, expanded upon the ideas of earlier educators including Plato, Aristotle, Confucius, Lao Tzu, Solomon, and Buddha (Houston, 1988) (Vol 6, Issue 3, p. 23).

- period: Skleidžiantis teorinei pedagoginei minčiai Nepriklausomoje (tarpukario) Lietuvoje, ugdymo sq̨vokq įveda S. Šalkauskis (Vol 122, Issue 2, p. 
19); On this account, it seems reasonable to conclude, as Olds, Leydens, and Miller (1999) did two decades ago, that FYC assessment research tends to be anecdotal and/or idiosyncratic, largely owing to reliance on 'stakeholders' satisfaction' ( $p$. 120) measured via questionnaire surveys (Vol 7, Issue 1, p. 10)

Scientific discoveries, results of scientific activity comprise the second group of scientific subject attributes used by authors of both languages by frequency in the context of all attributes (Picture 2). They highlight the most essential discoveries, prepared scientific works or other input into scientific activity of quoted authors. These attributes constitute 58\% in Lithuanian texts and even $96 \%$ of all supplementary attributes in English texts. It is obvious that English authors highly value scientific achievements of their colleagues emphasizing their recognition in the scientific society of educational area: Monografijos „Universiteto edukacine galia“ autoriu požiūriu, aukštasis mokslas turi pasižymèti specifinèmis savybemis, kurias laiduoja institucine autonomija ir akademiné laisvé (Vol 122, Issue 2, p. 80); Socialinis įstraukimas grindžiamas ekologinés sistemu teorijos nuostatomis (Zastrow, 2003, Rogers, 2005), atskleidžiančiomis individo ir aplinkos santykiu disfunkcionaluma (sutrikdyma) ir ju priežastis, paieška vidiniu ir išoriniu veiksnių ir priemoniu jiems pašalinti, siekiant pozityvios žmogaus sq̨veikos ir prisitaikymo prie aplinkos, igalinančios darnu žmogaus ir visuomenés vystymąsi ( Vol 124, Issue 4, p. 94). In a study of adult learners, Cox (2005) refers to the research of Seagraves et al. (1996) that differentiated between learning for work, learning at work, and learning through work (Vol 6, Issue 3 p.35); Drawing on Wang and Li's (2011) work, we sought to develop a mentorship model but soon became aware that we had different expectations of supervision from the student, which we attempted to address during meetings using a range of techniques (Vol 7, Issue 1, p. 4).

\section{Subjective attributes of science.}

Having analysed and compared the selected non-author language examples in Lithuanian and English scientific articles a tendency is envisaged that both Lithuanian and English authors do not prefer evaluating the subject of non-author language. There were no emotional evaluation attributes found either in Lithuanian or English educational texts. There were only a few cases of logic evaluation. Referring to the performed analysis, most frequently article authors convey objective information, avoid subjectivity. If subjective evaluation cases occur in scientific educational texts then it is claimed that subject is always described positively.

In texts of Lithuanian authors, a part of speech which is employed to provide the reader with reliability, validity of the given information is adverbs, e.g. teisingai, išsamiai, taikliai, pagristai, kompetetingai, in texts of English authors importantly, strongly, seemingly, interestingly, etc. For instance, Kompetentingai 
B. Bitino mokslinį indèli i žmogaus ir žmonijos ugdomuju galių šiuolaikiškq ir inovatyvu tobulinima nusake prof. E. Martišauskienè, teigdama, kad šis mokslinis veikalas „atskleidžia fundamentines aukléjimo idejas, technologijas ir pedagoginès diagnostikos pagrindus, taip sudarydamas realias prielaidas ugdytojams kompetentingai, inovatyviai plètoti edukacinę veikla, kurios svarba šiuolaikiniame pasaulyje tampa vis akivaizdesné" (Bitinas, 2013c, 36) (Vol 124, Issue 4, p. 12). Z kartos santykị su technologijomis taikliai apibūdino A. Cross-Bystrom (2010) (Vol 122, Issue 2, p. 110). Importantly, ...., the aims or purpose of a group can also function as a group norm (Postmes et al., 2001a) (Vol 7, Issue 2, p. 37); Seemingly agreeing with this, Urdan et al. (1995) advocate teamwork, authentic roles in the community, and recognition for taskmaster by peers and adults (Vol. 7, Issue 2, p. 74).

The author of a scientific text expresses his personal relationship with the conveyed information with the help of such adverbs, he shows his approval of declared thoughts.

It ought to be mentioned that subjective evaluation in Lithuanian articles is expressed by adjectives: aktualus, įdomus, žymus, garsus, unikalus, svarbus, e.g.: İomu fakta atskleidžia J. Račkauskas (1974), paaiškinęs vieno žymiausiu Apšvietos epochos švietėjų J. J. Rousseau ryši su Edukacinès komisijos steigimu (Vol 122, Issue 2, p. 7). Tai unikalus darbas, kai iškilus edukologijos mokslininkas visuotiniu désniu kontekste sisteminiu, istoriniu aspektu sintetina ugdymo esmes ir prasmes, nes būtent „ugdymo realybę pačiu aukščiausiu apibendrinimo lygiu nagrineja filosofija" (Bitinas, 2013a, 269)( Vol 124, Issue 4, p. 18). In English articles, adjectives are also abundant as well as verbs highlighting approval of thoughts of a quoted author, e.g. Anders and Miranda (2011) provide an extensive survey of this research area, and compare in detail several music constraint systems that allow users to model their own music theories (Vol 6, Issue 1, p. 5). A rule proposed by Sandred (2003) enforces an alignment between simultaneous parts that could be called quasi homophony, or a rhythmic hierarchy (Volume 6, Issue 1, p. 8).

Unlike Lithuanian, in English texts, in order to emphasize agreement with the thoughts of a quoted author idiomatic expressions are employed, e.g. It is clear that Boekaerts (1999) conceptualises learning is as a dynamic state of interaction and mutual reinforcement between the student and their environment (Vol 6, Issue 3, p. 33). In a sense, Entwistle et al. (2002) advocated an integrated model of learning that involved both internal and external regulation of students learning (Vol 6, Issue 3, p. 33). It is evident from the analysed texts that adjective usage by Lithuanian authors always stresses achievements of scientific activity of nonauthor subject, attitude to their scientific merits, performed studies, etc. Whilst English authors do not highlight achievements of scientific activity, merits, etc. 
Having compared the discussed articles some differences can be specified, i.e. authors of Lithuanian scientific articles are not inclined to express their subjective opinion with regard to the quoted author and / or his text whereas English authors are liable to contradict the quoted authors in rare cases, e.g. In contrast to Tufte's (2003) criticism, the sequential nature of a PowerPoint presentation was viewed as beneficial, rather than limiting as it provided a focal point (Vol 7, Issue 1, p.72).

The choice of Lithuanian authors not to criticise the quoted authors can be explained by one of the requirements of scientific style, i.e. objectivity. As scientific information must be objective and very accurate the text authors refer to quoted authors and their works only positively as otherwise it can provoke doubts about the accuracy of declared scientific information.

\section{Conclusions}

Not only did inter-language (Lithuanian and English) analysis of scientific articles of educational area reveal universal features of academic discourse but it allowed to envisage certain evaluative aspects of non-author language subject of academic text, identify characterisation tendencies of a quoted author, also it contributed to rendering of academic discourse peculiarities determined by diverse academic cultures.

Intertextuality as a certain feature of academic culture most frequently occurs in scientific texts by quoting (directly or paraphrasing). It is a frequent phenomenon in both Lithuanian and English texts of education area although English texts are more intertextual, they are more distinguished by interaction of the author and foreign text.

Analysing usage of direct and paraphrased citations in scientific articles it was denoted that paraphrased citations are more frequent in texts of both languages. Although they are significantly dominant and much more frequent than direct citations in English texts whilst these differences are not so significant in Lithuanian texts. These results indicate a greater preference of English authors to interpret and emphasize quoted material itself rather than convey the thoughts of the other author precisely in comparison with Lithuanian authors. Referring to the mentioned insignificant difference, it is possible to state that partially similar academic citation traditions of both languages were ascertained.

Studying reference integration into sentence structure it was determined that non-integral references prevail in academic discourse of both languages. Hence, authors of scientific articles of education area of both languages prefer to provide information but not to define its author.

Investigating relation between direct and paraphrased citations and their reference integration into sentence structure interesting inter-language quoting tendencies were observed. It was determined that having chosen a direct quoting method English authors are not inclined to integrate their references into sentence 
structure paraphrasing citations, they are also more liable not to integrate references. Relation between direct and paraphrased citations and integral and non-integral references in texts of Lithuanian authors is less apparent.

Both Lithuanian and English educational texts do not exhibit diversity of quoted author expression. There were no examples found conveying all possible semantic meanings of attributes of both languages. Thus, prevalence of neutral attributes of science subjects and basically similar aspects of usage of some attributes (surname / name and surname, nationality or residence) show general quoting traditions determined by universal regularities of scientific texts rather than a certain language and culture. On the other hand, certain tendencies peculiar for texts of one or the other language and reflecting specific features of science subject evaluation were observed. Scientific discoveries, scientific activity results are highlighted in articles of native English authors whereas Lithuanian authors put emphasis on scientific or professional activity and time. Moreover, it is indispensable to point that every text reflects personality of the author of the article, thus the choice of one or another means of expression can be determined by the author's personal qualities.

Subjective attributes in educational texts of both languages constitute only a small part of all selected attributes respectively. It ought to be noted that only logic evaluation dominates. Cases of emotional evaluation in educational texts of both Lithuania and English authors were not identified.

Referring to the research data, an assumption can be made that authors of Lithuanian scientific articles are not liable to express subjective opinion of the quoted author and / or his texts respectively. It can be explained by one of the requirements of scientific style, i.e. objectivity while English authors do express their contradiction in rare cases.

The executed research presents numerous possibilities for further research. This article focuses on inter-language (Lithuanian and English) academic discourse research of one area of science exclusively. Further interdisciplinary (soft and hard sciences or closely related science areas) research of expression evaluation of a quoted author in academic discourse could contribute to expose text creating traditions of different / related science areas and fields and determine universal qualities specific for many disciplines and what is peculiar for distinct areas of science.

\section{Sources}

Journal of Pedagogic Development. https://journals.beds.ac.uk/ojs/index.php/jpd/issue/archive Pedagogika / Pedagogy. http://www.pedagogika.leu.lt/index.php/Pedagogika 


\section{References}

Bednarek, M. (2006). Evaluation in Media Discourse: Analysis of a Newspaper Corpus. New York: Continuum.

Bell, A. (1991). The Language of News Media. Oxford: Blackwell.

Bitinienè, A. (2005). Mokslinis stilius ir jo intertekstualumas. Žmogus ir žodis, 1, 68-72.

Breivega, K.R., Dahl, T. \& Fløttum, K. (2002). Traces of self and others in research articles. A comparative pilot study of English, French and Norwegian research articles in medicine, economics and linguistics. International Journal of Applied Linguistics, 12 (2), 218-239.

Compagnon, A. (2000 [1998]). Il demone della teoria. Letteratura e senso comune, traduzione di Monica Guerra. Torino: Einaudi.

Čičirkaitè, R. (2005). Lingvistiniai reklamos tekstų požymiai. Žmogus ir žodis, 7 (1), 73-77.

Damošius, S. (2007). Vertinimo raiška mokslinio stiliaus tekstuose. Lituanistica, 53 (4), 51-62.

Duchovskis, P. (2003). Mokslinio straipsnio rengimas. Vagos. Mokslo darbai, 57 (10), 131-137.

Duszak, A. (1994). Academic discourse and intellectual styles. Journal of Pragmatics 21 (3), 291-313.

Flottum, K., Dahl, T. \& Kinn, T. (2006). Academic Voices: across languages and disciplines. John Benjamins Publishing Company: Amsterdam/Philadelphia.

Hood, S. (2010). Appraising Research: Evaluation in Academic Writing. Palgrave Macmillan Publishing Company.

Hyland, K. (1998). Hedging in Scientific Research Articles. John Benjamins Publishing Company: Amsterdam/Philadelphia.

Hyland, K. (1999). Academic attribution: citation and the construction of disciplinar knowledge. Applied Linguistics, 20 (3), 341-367.

Hyland, K. (2005). Metadiscourse: Exploring Interaction in Writing. London/New York: Continuum.

Hunston, S., Thompson, G. (2000). Evaluation in Text: Authorial Stance and the Construction of Discourse. New York: Oxford University Press.

Latour, B. (2002). Science in action. Harvard University Press.

Martin Martin, P. (2003). Personal attribution in English and Spanish scientific texts. Bells: Barcelona English language and literature, 12. URL: http://www.raco.cat/index.php/Bells/article/view/82918/108653.

Martin, J., White, P. (2006). The Language of Evaluation: appraisal in English. Palgrave Macmillan Publishing Company.

Melnikova, I. (2003). Intertekstualumas: teorija ir praktika. Vilnius: Vilniaus universiteto leidykla. 
Myers, G. (1989). The pragmatics of politeness in scientific articles. Applied Linguistics, 10, 1-35.

Mur Dueñas, P. (2007). 'I/we focus on ...': A cross-cultural analysis of self-mentions in business management research articles. Journal of English for Academic Purposes, 6(2), 143-162.

Petrauskaitė, R., Šinkūnienė, J. (2015). Dar kartą apie intertekstualumą. Ką jis sako apie mokslinį tekstą? Kalbotyra, 67, 67-85.

Petrènienè, O. (2005). Mokslo subjektų atributų raiška tekstuose. Žmogus ir žodis: didaktine lingvistika, 7 (1), 92-95.

Ryvitytė, B. (2005). Vertinimo raiška lingvistinių knygų recenzijose. Žmogus ir žodis: didaktine lingvistika, 7 (1), 96-101

Ryvitytè, B. (2008). Evaluation in linguistics book reviews in English and Lithuanian. PhD dissertation. Vilnius: Vilniaus universitetas.

Ruskan, A. (2012). Evidential adjectives in Lithuanian academic discourse. Kalbotyra, 64 (3), 103-123.

Smetona, A. \& Usonienė A. (2012). Autoriaus pozicijos adverbialai ir adverbializacija lietuvių mokslo kalboje. Kalbotyra, 64(3), 124-139.

Swales, J. M. (1990). Genre Analysis: English in academic and research settings. Cambridge: Cambridge University Press.

Šinkūnienè, J. (2011). Autoriaus pozicijos švelninimas rašytiniame moksliniame diskurse: gretinamasis tyrimas. Vilniaus universitetas.

Šinkūnienè, J. (2010). Autoriaus pozicijos raiška asmeniniais įvardžiais rašytiniame akademiniame diskurse. Filologija, 15, 124-141.

Šinkūnienè, J. (2011). Autoriaus pozicijos švelninimas rašytiniame moksliniame diskurse: gretinamasis tyrimas. Daktaro disertacija. Vilnius: Vilniaus universitetas.

Šinkūnienè, J. (2012). Adverbials as Hedging Devices in Lithuanian Academic Discourse: a Cross-disciplinary Study. Multiple Perspectives in Linguistic Research on Baltic Languages, ed. by A. Usonienè, N. Nau \& I. Dabašinskienė. 138-168. Newcastle: Cambridge Scholars Publishing.

Šinkūnienè, J. (2014). Lietuviškojo humanitarinių ir socialinių moksly diskurso ypatybès. Vilnius: VU leidykla.

Šlepikienė R. \& Linkevičienė N. (2013). Autoriaus ir skaitytojo santykių raiška publicistinio stiliaus tekstuose: redakcinių straipsnių kokybinè analizè. Lietuviu kalba, 7, 1-19.

Vassileva, I. (1998). Who am I/who are we in academic writing? A contrastive analysis of authorial presence in English, German, French, Russian and Bulgarian. International Journal of Applied Linguistics, 8 (2), 163-190.

Voverienė, 0. (2013). Mokslotyra. Vilnius: Diemedis. 
White, H. D. (2004). Citation analysis and discourse analysis revisited. Applied Linguistics, 25 (1), 89-116.

\section{Contact}

Virginija Stankevičienè

Faculty of Social Sciences, Humanities and Arts

Mickevičiaus g. 37-1309, Kaunas, LT 44244

Lithuania

virginija.stankeviciene@ktu.lt 